\title{
Antitumor, Analgesic and Anti-inflammatory Activities of Glochidion multiloculare (Rottler ex Willd) Voigt
}

\author{
Selina Kabir ${ }^{1}$, Ronok Zahan², Abdullah Mohammad Sarwaruddin Chowdhury', Mohammad \\ Rashedul Haque ${ }^{3}$ and Mohammad Abdur Rashid ${ }^{3}$
}

${ }^{1}$ Department of Applied Chemistry \& Chemical Engineering, University of Dhaka, Bangladesh.

${ }^{2}$ Department of Pharmacy, Rajshahi University, Bangladesh.

${ }^{3}$ Department of Pharmaceutical Chemistry, University of Dhaka, Bangladesh.

Received: May 20, 2015; Accepted: June 25, 2015; Published (Web): July 21, 2015

\begin{abstract}
The antitumor, analgesic and anti-inflammatory activities of the methanol extract (MEGM) of Glochidion multiloculare and its petroleum ether (PEFGM), carbon tetrachloride (CTFGM) and chloroform (CHFGM) soluble fractions were investigated. The antitumor activity of the extract/fractions was determined against Ehrlich's ascites carcinoma (EAC) in mice at $20 \mathrm{mg} / \mathrm{kg}$ body weight intraperitoneally. Increase of survival time by $24 \pm 0.12,26 \pm 0.40,21 \pm 0.12$ and $27 \pm 0.42$ days was observed by the MEGM, PEFGM, CTFGM and CHFGM treated tumor bearing mice compared to the control group (20 \pm 0.12 days). Hematological studies revealed that heamoglobin $(\mathrm{Hb})$ content was decreased in EAC treated mice whereas restoration to normal levels was observed in extract/fractions treated animals. Significant decrease in RBC and increase in WBC counts were observed in extract/fractions treated animals when compared to EAC affected animals. Both extract and fractions at the dose of $100 \mathrm{mg} / \mathrm{kg}$ b.w. significantly increased the pain threshold in tail immersion method and reduced the writhing caused by acetic acid induced method. The MEGM, PEFGM, CTFGM and CHFGM showed anti-inflammatory activities at 100 $\mathrm{mg} / \mathrm{kg}$ b.w. This is the first report of antitumor, analgesic and anti-inflammatory potential of G. multiloculare.
\end{abstract}

Key words: Glochidion multiloculare, antitumor, analgesic, anti-inflammatory

\section{Introduction}

According to the estimates of the WHO, more than $80 \%$ of people in developing countries depend on traditional medicine for their primary health needs. A recent survey shows that more than $60 \%$ of cancer patients use vitamins or herbs as therapy (Madhuri and Pandey, 2008; Sivalokanathan et al., 2005). There is evidence in the literature that anti-inflammatory compounds could be also anticancerous. These compounds could modify the redox environment of cancer cells and thus their behavior (Schafer and Buettner, 2001).

Glochidion was regarded as a genus of the family Euphorbiaceae, which consists of monoecious, rarely dioecious trees or shrubs. But molecular phylogenetic studies have shown that Phyllanthus is paraphyletic over Glochidion. A recent revision of the family Phyllanthaceae has subsumed Glochidion into Phyllanthus (Hoffmann et al., 2006). Glochidion multiloculare (Roxb. ex Willd.) Muell.-Arg., Phyllanthaceae (synonym:
Phyllanthus multilocularis), locally known as Aniatori, Keotomi, Keoura, Paniatori, Pannyaturi is an evergreen shrub or small tree. The plant is found in Bhutan, India, Myanmar, Nepal and Bangladesh. Traditionally many Phyllanthus species are used in haemorrhoids, diarrhoea, dysentery, anaemia, jaundice, dyspepsia, insomnia etc. and some of them can induce diuresis (Ghani, 1998). Previous phytochemical investigations revealed the isolation of glochidiol, glochilocudiol, glochidone and dimedone (Talapatra et al., 1973). Many secondary metabolites were isolated from Glochidion species, including tannins (Chen et al., 1995), glycosides (Otsuka et al., 2003), lignans (Otsuka et al., 2000), terpenoids (Hui and Li, 1976).

To the best of our knowledge from the literatures, the biological activities of G. multiloculare were not explored extensively. The objectives of the present study were to examine the antitumor, analgesic and anti-inflammatory potential of G. multiloculare.

Correspondence to: Mohammad Abdur Rashid; Tel.: 880-2-9661920, Ext. 8137; Fax: 880-2-9667222; E-mail: rashidma@du.ac.bd 


\section{Materials and Methods}

Plant materials: The stem bark of G. multiloculare was collected from Modhupur, Tanghail in the month of April, 2009 and identified by Mr. Sarder Nasir Uddin, Scientific Officer, Bangladesh National Herbarium, Dhaka, where a voucher specimen (DACB- 34200) representing this collection has been deposited.

Chemicals: Sodium chloride, propylene glycol, trypan blue, methylene blue, methyl violet, sodium sulphate, and bleomycin were purchased from Merck Limited, Mumbai, India. Diclofenac-Na and indomethacin were collected from Square Pharmaceuticals Ltd., Bangladesh. All other chemicals and reagents were used of highest analytical grade.

Preparation of extract: The air dried and powdered plant material (1000 g) was extracted with methanol (3000 $\mathrm{mL}$ ) for 7 days) at room temperature with occasional shaking and stirring. The extractive was filtered through fresh cotton plug and followed by Whatman no. 1 filter paper. The filtrate was then concentrated by a Buchii rotavapor at low temperature and pressure and to afford methanol (MEGM) extract (41.7398 g). The cold methanol extract $(10 \mathrm{~g})$ was subjected to solvent-solvent partitioning using modified Kupchan protocol (VanWagenen et al., 1993). The extract was partitioned successively into petroleum ether (PEFGM), carbon tetrachloride (CTFGM) and chloroform (CHFGM) soluble fractions.

Animal: Swiss albino mice (25-30 g) of either sex were used for assessing the antitumor activity. The animals were maintained under standard laboratory conditions and had free access to food and water ad libitum. The animals were allowed to acclimatize to the environment for 7 days prior to experimental session. They were divided into seven groups, each consisting of twelve animals which were fasted overnight prior to the experiments. Experiments with the animals were performed in accordance with guidelines of the Institutional Animal Ethics Committee, Department of Applied Chemistry \& Chemical Engineering, University of Rajshahi, Rajshahi, Bangladesh.

Acute toxicity: The acute oral toxicity of the plant extract in Swiss albino mice was studied as per established protocol (Lorke, 1983).

\section{Biological assays}

\section{In vivo antitumor activity}

Transplantation of tumor: Ehrlich's ascites carcinoma (EAC) cells were obtained from Indian Institute of Chemical Biology (IICB), Kolkata, India. The EAC cells were maintained in vivo in Swiss albino mice by intraperitoneal transplantation of $2 \times 10^{6}$ cells per mouse after every 10 days. Ascitic fluid was drawn from EAC tumor bearing mice at the $\log$ phase (days $7-8$ of cell implantation) of the tumor cells. Each animal received 0.1 $\mathrm{ml}$ of tumor cell suspension containing $2 \times 10^{6}$ tumor cells intraperitoneally.

Treatment schedule: 84 Swiss albino mice were divided into seven groups $(\mathrm{n}=12)$ and given food and water ad libitum. All the animals in each group except Group-I received EAC cells $\left(2 \times 10^{6}\right.$ cells/mouse i.p.). This was taken as day ' 0 '. Group-I served as normal saline control ( $5 \mathrm{ml} / \mathrm{kg}$ i.p.) and Group-II served as EAC treated control. After $24 \mathrm{~h}$ of EAC transplantation, Group-III, Group-IV, Group-V and Group-VI received MEGM, PEFGM, CTFGM and CHFGM of G. multiloculare stem bark at $20 \mathrm{mg} / \mathrm{kg}$ i.p. for 9 consecutive days. Group-VII received reference drug bleomycin $(0.3 \mathrm{mg} / \mathrm{kg}$ i.p) for 9 consecutive days (Rana and Khanam, 2002). After $24 \mathrm{~h}$ of last dose and $18 \mathrm{~h}$ of fasting, 6 animals from each group were sacrificed by cervical dislocation to measure antitumor and hematological parameters and the rest were kept with food and water ad libitum to check percentage increase in life span of the tumor bearing host. The antitumor activity of the extract/ fractions of $G$. multiloculare was measured in EAC bearing animals with respect to the following parameters.

Determination of tumor volume and weight: The mice were dissected and the ascitic fluid was collected from the peritoneal cavity. The volume was measured by taking it in a graduated centrifuge tube and weighed immediately.

Tumor cell count: The ascitic fluid was taken in a WBC pipette and diluted 100 times with phosphate buffer saline (PBS). Then a drop of the diluted cell suspension was placed on the Neubauer's counting chamber and the number of cells in the 64 small squares was counted.

Viable/nonviable tumor cell count: The viability and non-viability of the cells were checked by trypan blue assay with the help of microscope. The cells were stained with trypan blue $(0.4 \%$ in normal saline) dye. The cells 
that did not take up the dye were viable and those that took the dye were nonviable. The viable and nonviable cells were counted using the following equation:

Cell count $=($ Number of cells $\times$ dilution factor $) /$ (Area $\times$ thickness of liquid film)

Determination of median survival time and percentage increase in life span: The mortality was monitored by recording percentage increase in life span (\%ILS) and median survival time (MST) (Sur and Ganguly, 1994).

Hematological parameters: Collected blood samples were used for the estimation of hemoglobin $(\mathrm{Hb})$ content, red blood cell (RBC) and white blood cell count (Armour et al., 1965).

\section{Analgesic activity}

Tail flick test: The animals were divided into six groups with six mice in each group. Group I animals received vehicle (1\% Tween 80 in water, $10 \mathrm{~mL} / \mathrm{kg}$ body weight, negative control) animals of Group VI received Diclofenac-Na at $10 \mathrm{mg} / \mathrm{kg}$ body weight (positive control), while animals of Group II, Group III, Group IV and Group $\mathrm{V}$ were treated with $100 \mathrm{mg} / \mathrm{kg}$ body weight (p.o.) of the MEGM, PEFGM, CTFGM and CHFGM of $G$. multiloculare. Then $1-2 \mathrm{~cm}$ of the tail of mice was immersed in warm water kept at constant temperature of $60{ }^{\circ} \mathrm{C}$ and the reaction time was the time taken by the mice to deflect their tails was noted. The first reading was discarded and the reaction time was recorded as a mean of the next three readings. A latency period of $20 \mathrm{sec}$ was defined as complete analgesia and the measurement was then stopped to avoid injury to mice. The latent period of the tail-flick response was determined before and 0, 30, 60 and $90 \mathrm{~min}$ after the oral administration of drugs (Toma et al., 2003).

Acetic acid-induced writhing test: The analgesic activity of the samples was also studied using acetic acidinduced writhing model in mice. Test samples and vehicle were administered orally $30 \mathrm{~min}$ before intraperitoneal administration of $0.7 \%$ acetic acid but Diclofenac-Na was administered intraperitonially $15 \mathrm{~min}$ before injection of acetic acid. After an interval of $5 \mathrm{~min}$, the mice were observed for specific contraction of body referred to as 'writhing' for the next $10 \mathrm{~min}$ (Ghule et al., 2011).

\section{Anti-inflammatory activity}

Carrageenan induced paw edema test in mice: Mice were divided into six groups containing six animals in each. The test groups received $100 \mathrm{mg} / \mathrm{kg}$, p.o. of each extract/fractions. The positive control group received indomethacin $(10 \mathrm{mg} / \mathrm{kg}$, p.o. $)$ while the negative control group received $3 \mathrm{~mL} / \mathrm{kg}$ of $1 \%$ Tween 80 in water. After 1 $\mathrm{h}, 0.1 \mathrm{~mL}$ of $1 \% \mathrm{w} / \mathrm{v}$ carrageenan suspension in normal saline was injected into the sub plantar tissue of the right hind paw (Winter et al., 1962). The paw volume was measured at 1,2, 3 and $4 \mathrm{~h}$ after carrageenan injection using a micrometer screw gauge. The percentage inhibition of the inflammation was calculated from the formula: $\%$ inhibition $=\left(1-D_{t} / D_{0}\right) \times 100$, whereas $D_{o}$ was the average inflammation (hind paw edema) of the control group of mice at a given time and $\mathrm{D}_{t}$ was the average inflammation of the drug treated (i.e. extract/fractions or reference indomethacin) mice at the same time (Gupta et al., 2005).

Statistical analysis: Antitumor data are expressed as mean \pm S.E.M. $(\mathrm{n}=12)$. Statistical significance $(\mathrm{p})$ calculated by Student's $t$ test. $P<0.001$ and $<0.05$ were considered to be statistically significant. Analgesic and anti-inflammatory data are expressed as mean \pm S.E.M. (n $=6)$. Statistical significance (p) calculated by ANOVA followed by Dunnett's test $(\mathrm{p}<0.01$ and $\mathrm{p}<0.001)$ were considered to be statistically significant.

\section{Results and Discussion}

The acute toxicity study was conducted to establish the therapeutic index, i.e., the ratio between the pharmacologically effective dose and the lethal dose on the same strain and species. The extract/fractions of $G$. multiloculare were safe up to a dose of $500 \mathrm{mg} / \mathrm{kg}$ (p.o.) body weight which agrees with the previous study (Rahman et al., 2011). Behavior of the animals was closely observed for the first $3 \mathrm{~h}$ then at an interval of every $4 \mathrm{~h}$ during the next $48 \mathrm{~h}$. The extract did not cause mortality in mice during $48 \mathrm{~h}$ of observation but little behavioral changes, locomotors ataxia, diarrhea and weight loss were observed. Food and water intake had no significant difference among the groups studied.

Antitumor activity of extract/fractions against EAC tumor bearing mice was assessed by the parameters such as tumor volume, tumor weight, cell count (viable and 
non-viable), mean survival time and $\%$ increase of life span. The results are shown in table 1 . The tumor volume, tumor weight and viable cell count were found to be significantly $(\mathrm{p}<0.001)$ increased and non-viable cell count was significantly $(\mathrm{p}<0.001)$ low in EAC control animals when compared with normal saline control animals. Administration of MEGM, PEFGM, CTFGM and CHFGM at a dose of $20 \mathrm{mg} / \mathrm{kg}$ significantly $(\mathrm{p}<0.05)$ decreased the tumor volume, tumor weight and viable cell count. Furthermore, the median survival time was increased to $25 \pm 0.32(\%$ ILS $=24.6), 26 \pm 0.10(\%$ ILS $=$
30.3), $23 \pm 0.19(\%$ ILS = 20.5) and $27 \pm 0.42(\%$ ILS = 29.01) after administration of MEGM, PEFGM, CTFGM and CHFGM at a dose of $20 \mathrm{mg} / \mathrm{kg}$ b.w., respectively.

Hematological parameters (Table 2) of tumor bearing mice after 14 days were found to be significantly altered compared to the normal saline group. The total WBC count was found to be increased with a reduction of $\mathrm{Hb}$ content and RBC. The total number of RBC showed a modest change. At the same time interval on extract/fractions at a dose of $20 \mathrm{mg} / \mathrm{kg}$ restored all the altered hematological parameters to almost near normal.

Table 1. Effect of G. multiloculare on tumor volume and weight, mean survival time (MST), percentage increase life span (\% ILS), viable and non-viable tumor cell count in EAC bearing mice.

\begin{tabular}{lcccccc}
\hline Parameter & EAC control & MEGM & PEFGM & CTFGM & CHFGM & Bleomycin \\
\hline Tumor volume (ml) & $3.1 \pm 0.21$ & $0.89 \pm 0.29$ & $0.76 \pm 0.34^{*}$ & $1.12 \pm 0.21^{*}$ & $0.72 \pm 0.34^{*}$ & $0.51 \pm 0.21^{*}$ \\
Tumor weight $(\mathrm{g})$ & $3.90 \pm 0.24$ & $1.82 \pm 0.24$ & $1.25 \pm 0.21^{*}$ & $2.01 \pm 0.11^{*}$ & $1.22 \pm 0.21^{*}$ & $0.61 \pm 0.11^{*}$ \\
MST (days) & $20 \pm 0.12$ & $24 \pm 0.12$ & $26 \pm 0.40$ & $21 \pm 0.12$ & $27 \pm 0.42$ & $42.6 \pm 0.12$ \\
$\%$ ILS & 00.0 & 22.2 & 27.2 & 19.81 & $29.01 \%$ & 98.81 \\
Viable cell (x 10 ${ }^{7}$ cell/ml) & $8.1 \pm 0.22$ & $0.96 \pm 0.22^{*}$ & $0.66 \pm 0.05^{*}$ & $1.52 \pm 0.05^{*}$ & $0.50 \pm 0.05^{*}$ & $0.5 \pm 0.05^{*}$ \\
Non-viable cell (x 107 cell/ml) & $0.5 \pm 0.24$ & $2.21 \pm 0.24^{*}$ & $2.13 \pm 0.54^{*}$ & $2.07 \pm 0.05^{*}$ & $2.01 \pm 0.54^{*}$ & $3.3 \pm 0.05^{*}$ \\
Total cell (x 10 cell/ml) & $8.6 \pm 0.15$ & $3.18 \pm 0.15$ & $2.79 \pm 0.21$ & $3.59 \pm 0.05$ & $2.51 \pm 0.21$ & $3.8 \pm 0.05^{*}$ \\
Viable \% & 94.18 & 30.51 & 23.66 & 42.34 & $23.31 \%$ & 13.15 \\
Non-viable \% & 5.82 & 69.49 & 76.34 & 57.66 & 76.84 & 86.85 \\
\hline
\end{tabular}

Each point represent the mean \pm SEM. $(n=6),{ }^{*} p<0.05$ statistically significant when compared with EAC control group.

Table 2. Effect of G. multiloculare on hematological parameter in EAC bearing mice.

\begin{tabular}{lccc}
\hline Treatment & RBC $\left(\right.$ cell $\left.\times 10^{3} / \mathrm{mm}^{3}\right)$ & WBC $\left(\right.$ cell $\left.\times 10^{3} / \mathrm{mm}^{3}\right)$ & Hemoglobin $(\mathrm{g} \%)$ \\
\hline Normal saline control & $5.69 \pm 0.12$ & $3.92 \pm 0.32$ & $13.90 \pm 3.1$ \\
EAC control & $3.91 \pm 0.80^{*}$ & $5.94 \pm 0.52^{*}$ & $4.95 \pm 1.80^{*}$ \\
Bleomycin (0.3 mg/kg b.w.) & $5.18 \pm 0.12^{* *}$ & $3.35 \pm 0.83^{* *}$ & $12.89 \pm 2.93^{* * *}$ \\
MEGM (20 mg/kg b.w.) & $4.37 \pm 0.16^{* *}$ & $4.59 \pm 0.12^{* *}$ & $7.93 \pm 1.62^{* *}$ \\
PEFGM (20 mg/kg b.w.) & $4.83 \pm 0.61^{* *}$ & $4.49 \pm 0.39^{* *}$ & $8.73 \pm 1.01^{* *}$ \\
CTFGM (20 mg/kg b.w.) & $4.01 \pm 0.29^{* *}$ & $4.97 \pm 0.32^{* *}$ & $7.23 \pm 1.79^{* *}$ \\
CHFGM (20 mg/kg b.w.) & $4.81 \pm 0.61^{* *}$ & $4.44 \pm 0.39^{* *}$ & $8.50 \pm 1.00^{* *}$ \\
\hline
\end{tabular}

Each point represent the mean \pm SEM. $(n=6), * p<0.001$ statistically significant and $* * p<0.005$ statistically significant; when compared with EAC control group.

In the antitumor activity test, a regular and quick increase in ascetic tumor volume was observed. A quick increase of fluid with tumor growth would be a way to meet the nutritional requirement of tumor cells (Prasad and Giri, 1994). Treatment with extract/fractions reduced the intraperitonial tumor burden, thereby fall the tumor weight, cell growth and increased the life span of the tumor bearing mice. Therefore, extract/fractions increased the life span of EAC bearing mice may be by declining the nutritional fluid volume and delaying the cell division (Sur et al., 1997). Anemia encountered in ascites carcinoma usually due to iron deficiency and finally leads to reduced RBC number (Gupta et al., 2007). Administration of extract/fractions reversed the hemoglobin content, thus supporting its haematopoietic activity without inducing myelotoxicity. Earlier study of Glochidione species indicated the presence of tannins, glycosides, lignan and terpenoid. The mechanism of anticancer activity of 
phenolics (tannins) could be by troubling the cellular division during mitotis at the telophase stage (Gawron and Kruk, 1992). Therefore, it can be taken into evidence that the plant extract/fractions exhibited antitumor activity through these antitumor phytochemicals.

The tail withdrawal reflex time following administration of the MEGM, PEFGM, CTFGM and CHFGM were found to statistically significant $\left({ }^{*} \mathrm{p}<0.01\right.$ and $\left.{ }^{* *} \mathrm{p}<0.001\right)$ and was comparable to the reference drug Diclofenac-Na (Table 3).
Table 4 shows the effects of the extract/fractions on acetic acid-induced writhing in mice. The oral administration of extract/fractions significantly $(* \mathrm{p}<0.01$ and $* * \mathrm{p}<0.001)$ inhibited (\% inhibition of writhing of MEGM, PEFGM, CTFGM and CHFGM were 70, 66.36, 83.25 and 84.09 , respectively) writhing response induced by acetic acid.

Table 3. Effects of $G$. multiloculare on tail withdrawal reflex of mice induced by tail flick method.

\begin{tabular}{|c|c|c|c|c|c|}
\hline \multirow[t]{2}{*}{ Treatment group } & \multirow[t]{2}{*}{ Dose (mg/kg b.w.) } & \multicolumn{4}{|c|}{ Tail flick time } \\
\hline & & 0 Min & $30 \mathrm{Min}$ & 60 Min & 90 Min \\
\hline Vehicle control (1\% Tween-80) & - & $1.30 \pm 0.11$ & $1.35 \pm 0.12$ & $1.43 \pm 0.05$ & $1.40 \pm 0.11$ \\
\hline Standard (Diclofenac-Na) & 10 & $1.40 \pm 0.02$ & $2.26 \pm 0.25^{* *}$ & $3.13 \pm 0.10^{* *}$ & $3.06 \pm 20^{* * *}$ \\
\hline MEGM & 100 & $1.20 \pm 0.10$ & $1.38 \pm 0.10^{* *}$ & $2.31 \pm 0.15^{* *}$ & $1.48 \pm 0.10^{*}$ \\
\hline PEFGM & 100 & $1.6 \pm 0.20$ & $1.80 \pm 0.26^{* *}$ & $2.30 \pm 0.11^{\text {** }}$ & $1.53 \pm 0.08^{*}$ \\
\hline CTFGM & 100 & $1.6 \pm 0.12$ & $2.05 \pm 0.04^{* *}$ & $2.34 \pm 0.03^{* *}$ & $1.17 \pm 0.07^{*}$ \\
\hline CHFGM & 100 & $1.45 \pm 0.01$ & $1.53 \pm 0.21^{* *}$ & $1.91 \pm 0.16^{* *}$ & $1.23 \pm 0.10^{*}$ \\
\hline
\end{tabular}

Values are mean \pm SEM, $(n=6) ; * p<0.01$ and $* * p<0.001$, Dunnett's test as compared to control.

Table 4. Effects of the $G$. multiloculare on acetic acid-induced writhing in mice.

\begin{tabular}{lccc}
\hline Treatment group & Dose (mg/kg b.w.) & Number of writhing & \% Inhibition of writhing \\
\hline Vehicle control (1\% Tween-80) & & $110.0 \pm 10.23$ & - \\
Standard (Diclifenac-Na) & 10 & $15.0 \pm 3.25^{* *}$ & 86.36 \\
MEGM & 100 & $33.0 \pm 8.57^{* *}$ & 70 \\
PEFGM & 100 & $37.0 \pm 5.57^{* *}$ & 66.36 \\
CTFGM & 100 & $18.42 \pm 5.0^{* *}$ & 83.25 \\
CHFGM & 100 & $17.5 \pm 4.50^{* *}$ & 84.09 \\
\hline
\end{tabular}

Values are mean \pm SEM, $(n=6) ; * p<0.01$ and $* * p<0.001$, Dunnett's test as compared to control.

The dorsal horn of the spinal cord is gifted with several neurotransmitters and receptors which are the major targets for pain and inflammation (McCurdy and Scully, 2005). The tail immersion test was considered to be a selectivemethod to study compounds acting through opioid receptor. All the extract/fractions increased pain threshold, which indicates that it may act via centrally mediated analgesic mechanism (Elisabetsky et al., 1995). On the other hand, acetic acid-induced writhing response is a susceptible procedure to assess peripherally acting analgesics and represents pain sensation by triggering localized inflammatory response. The response is taken to be mediated by peritoneal mast cells (Ribeiro et al., 2000), acid sensing ion channels (Voilley, 2004) and the prostaglandin pathways (Hossain et al., 2006). The organic acid has also been postulated to act indirectly by inducing the release of endogenous mediators, which stimulates the nociceptive neurons that are responsive to NSAIDs and narcotics (Adzu et al., 2003).

However, Kerstein et al. (2009) recommend that, the inhibitory effect to pain response may be due to local increase of the intracellular $\mathrm{Ca}^{2+}$ ion which can affect TRPA1 (Transient Receptor Potential Ankyrin 1) activity resulting in analgesic action. So it is expected that the extract/fractions may hold substances that affect the metabolism of $\mathrm{Ca}^{2+}$ ions. Tannins are also found to have a 
contribution in antinociceptive activity (Ramprasath $e t$ al., 2006).

In the carrageenan induced paw edema test in mice, the extract/fraction showed inhibition on paw edema compared to the control group (Table 5).

Carrageenan test has been used as an experimental animal model for acute inflammation and is believed to be biphasic. The early phase $(1-2 \mathrm{~h})$ is mainly mediated by histamine, serotonin and increased synthesis of prostaglandins. The late phase is sustained by prostaglandin release and mediated by bradykinin, leukotrienes, polymorphonuclear cells and prostaglandins (Kaushik et al., 2012). As the extract/fractions significantly inhibited paw edema in the second phase and this finding suggests a possible inhibition of cyclooxygenase synthesis.

Table 5. Effects of $G$. multiloculare on carrageenan induced paw edema in mice.

\begin{tabular}{lccccc}
\hline Treatment group & Dose (mg/kg b.w.) & \multicolumn{4}{c}{ Paw edema volume (cm) } \\
\hline & & $1 \mathrm{H}$ & $2 \mathrm{H}$ & $3 \mathrm{H}$ & $4 \mathrm{H}$ \\
\cline { 2 - 6 } Vehicle control (1\% Tween-80) & & $1.23 \pm 0.11$ & $1.4 \pm 0.12^{* *}$ & $1.53 \pm 0.05^{* *}$ & $1.46 \pm 0.11^{* *}$ \\
Standard (Indomethacin) & 10 & $1.23 \pm 0.02$ & $1.16 \pm 0.25^{* *}$ & $1.13 \pm 0.10^{* *}$ & $1.06 \pm 0.20^{* *}$ \\
MEGM & 100 & $1.3 \pm 0.07$ & $1.2 \pm 0.05^{* *}$ & $1.0 \pm 0.07^{* *}$ & $0.9 \pm 0.045^{* *}$ \\
PEFGM & 100 & $1.25 \pm 0.04$ & $1.15 \pm 0.07^{* *}$ & $1.0 \pm 0.04^{* *}$ & $0.95 \pm 0.5^{* *}$ \\
CTFGM & 100 & $1.25 \pm 0.32$ & $1.2 \pm 0.07^{* *}$ & $1.0 \pm 0.25^{* *}$ & $0.9 \pm 0.07^{* *}$ \\
CHFGM & 100 & $1.3 \pm 0.45$ & $1.15 \pm 0.05^{* *}$ & $0.95 \pm 0.02^{* *}$ & $0.85 \pm 0.05^{* *}$ \\
\hline
\end{tabular}

Values are mean \pm SEM, $(n=6) ; * p<0.01$ and $* * p<0.001$, Dunnett's test as compared to control.

\section{Conclusions}

On the basis of our results, it may be concluded that the plant extract and fractions possess antitumor, analgesic and anti-inflammatory potential. However, further studies are necessary to examine the underlying mechanisms of these effects and to isolate the active compound(s) responsible for these pharmacological activities.

\section{Acknowledgement}

The authors are grateful to the Department of Applied Chemistry \& Chemical Engineering, University of Rajshahi, Rajshahi for providing laboratory facilities to carry out this research work.

\section{References}

Adzu, B., Amos, S., Kapu, S.D. and Gamaniel, K.S. 2003. Antiinflammatory and anti-nociceptive effects of Sphaeranthus senegalensis. J. Ethnopharmacol. 84, 169-173.

Armour, D.F.E., Blood, F.R. and Belden, D.A. 1965. The Manual for laboratory works in mammalian physiology $3^{\text {rd }}$ Edition. The University of Chicago Press, Chicago, pp. 4-6.

Chen, L.G., Yang, L.L., Yen, K.Y., Hatano, T., Yoshida, T. and Okuda, T. 1995. Tannins of euphorbiaceous plants. XIII: New hydrolyzable tannins having phloroglucinol residue from Glochidion rubrum BLUME. Chem. Pharm. Bull. 43, 2088-2090.
Elisabetsky, E., Arnador, T.A., Albuquerque, R.R., Nunes, D.S. and Carvalho, A.DoC.T. 1995. Analgesic activity of Psychotria colorata (Willd. ex R. and S.) Muell. Arg. alkaloids," J. Ethnopharmacol. 48, 77-83.

Gawron, A. and Kruk, G. 1992. Cytotoxic effect of xanthotoxol (8-hydroxypsoralen) on TCTC cells in vitro. Pol. J. Pharmacol. Pharm. 44, 51-57.

Ghani, A. 1998. Medicinal Plants of Bangladesh: Chemical Constituents and Uses. $1^{\text {st }}$ Edition, Asiatic Society of Bangladesh.

Ghule, R.S., Venkatnarayanan, R., Thakare, S.P., Jain, H. and Ghule, P.R. 2011. Analgesic activity of Cuscuta campestris Yuncker a parasitic plant grown on Nerium indicum Mill. $J$. Adv. Phar. Educ. Res. 1, 45-51.

Gupta, M., Mazumder, U.K., Halder, P.K., Kandar, C.C., Monikandan, L. and Senthil, G.P. 2007. Anticancer activity of Indigofera aspalathoides and Wedelia calendulaceae in swiss albino mice. Iranian J. Pharm. Res. 6, 141-145.

Gupta, M., Mazunder, U.K., Sambath, K.R., Gomath, P., Rajeshwar, Y. and Kakoti, B.B. 2005. Anti-inflammatory, analgesic and antipyretic effects of methanol extract from Bauhina racemosa stem bark in animal models. $J$. Ethnopharmacol. 98, 267-273.

Hoffmann, P., Kathriarachchi, H. and Wurdack, K.J. 2006. A revised phylogenetic classification of Phyllanthaceae (Malpighiales; Euphorbiaceae sensu lato). Kew. Bull. 61, 37-53. 
Hossain, M.M, Ali, M.S., Saha, A. and Alimuzzaman, M. 2006. Antinocicceptive activity of whole plant extracts of Paederia foetida. Dhaka Univ. J. Pharm. Sci. 5, 67- 69.

Hui, W-H. and Li, M-M. 1976. Lupene triterpenoids from Glochidion eriocarpum. Phytochemistry 15, 561-562.

Kaushik, D., Kumar, A., Kaushik, P. and Rana, A.C. 2012. Adv. Pharmacol. Sci. doi:10.1155/2012/245431, Article ID 245431 (2012).

Kerstein, P.C., Camino, D. del, Moran, M.M. and Stucky, C.L. 2009. Pharmacological blockade of TRPA1 inhibits mechanical firing in nociceptors. Mol. Pain 5, 19.

Lorke, D. 1983. A new approach to practical acute toxicity testing. Arch. Toxicol. 54, 275-187.

Madhuri, S. and Pandey, G. 2008. Some dietary agricultural plants with anticancer properties. Plant Arch. 8, 13-16.

McCurdy, C.R. and Scully S.S. 2005. Analgesic substances derived from natural products (natureceuticals). Life Sci. 78, 476-484.

Otsuka, H., Hirata, E., Shinzato, T. and Takeda, Y. 2000. Isolation of lignan glucosides and neolignan sulfate from the leaves of Glochidion zeylanicum (Gaertn) A. Juss. Chem. Pharm. Bull. 48, 1084-1086.

Otsuka, H., Kijima, H., Hirata, E., Shinzato, T., Takushi, A., Bando, M. and Takeda, Y. 2003. Glochidionionosides A-D: megastigmane glucosides from leaves of Glochidion zeylanicum (Gaertn.) A. Juss. Chem. Pharm. Bull. 51, 286290.

Prasad, S.B. and Giri, A. 1994. Antitumor effect of cisplatin against murine ascites Dalton's lymphoma. Indian J. Exp. Biol. 32, 155-162.

Rahman, M.H., Alam, M.B., Chowdhury, N.S., Jha, M.K., Hasan, M., Khan, M.M., Rahman, M.S. and Haque, M.E. 2011. Antioxidant, analgesic and toxic potentiality of Stephania japonica (Thunb.) Miers. Leaf. Int. J. Pharmacol. 7, 257-262.

Ramprasath, V.R., Shanthi, P. and Sachdanandam, P. 2006. Immunomodulatory and anti-inflammatory effects of Semecarpus anacardium LINN. Nut milk extract in experimental inflammatory conditions. Biol. Pharm. Bull. 29, 693-700.
Rana, A.Y.K.M.M. and Khanam, J.A. 2002. Aristolochia indica whole plant extract as an antineoplastic Agent. J. Med. Sci. 2, 202-205.

Ribeiro, R.A., Vale, M.L., Thomazzi, S.M., Paschoalato, A.B., Poole, S., Ferreira, S.H. and Cunha, F.Q. 2000. Involvement of resident macrophages and mast cells in the writhing nociceptive response induced by zymosan and acetic acid in mice. Eur. J. Pharmacol. 387, 111-118.

Schafer, F.Q. and Buettner, G.R. 2001. Redox state of the cell as viewed through the glutathione disulfide/glutathione couple. Free Rad. Biol. Med. 30, 1191-1212.

Sivalokanathan, S., Ilayaraja, M. and Balasubramanium, M.P. 2005. Efficacy of Terminalia arjuna (Roxb.) on Nnitrosodiethylamine induced hepatocellular carcinoma in rats. Indian J. Exp. Biol. 43, 264-267.

Sur, P. and Ganguly, D. K. 1994. Tea plant root extract (TRE) as an antineoplastic agent. Planta Med. 60, 106-109.

Sur, P., Bag, S.P. and Khanam, J.A. 1997. Choroacetohydroxamic acid as antitumor agent against Ehrlich ascites carcinoma in mice. Neoplasma 44, 197-201.

Talapatra, S.K., Bhattacharya, S., Maiti, B.C. and Talapatra, B. 1973. Structure of glochilocudiol. New triterpenoid from Glochidion multiloculare. Natural occurrence of dimedone. Chem. Ind. (London, United Kingdom) 21, 1033-1034.

Toma, W., Graciosa, J.S., Hiruma-Lima, C.A., Andrade, F.D.P., Vilegas, W. and Souza-Brita, A.R.M. 2003. Evaluation of the analgesic and antiedematogenic activities of Quassia amara bark extract. J. Ethnopharmacol. 85, 19-23.

VanWagenen, B.C., Larsen, R., Cardellina, J.H.I.I., Randazzo, D., Lidert, Z.C., and Swithenbank, C. 1993. Ulosantoin, a potent insecticide from the sponge Ulosareutzleri. J. Org. Chem. 58, 335-337.

Voilley, N. 2004. Acid-sensing ion channels (ASICs): new targets for the analgesic effects of non-steroid antiinflammatory drugs (NSAIDs). Curr. Drug Targets Inflamm. Allergy 3, 71-79.

Winter, C.A., Risley, E.A. and Nuss, G.W. 1962. Carrageenininduced edema in hind paw of the rat as an assay for antiiflammatory drugs. Pro. Soc. Exp. Biol. Med. 111, 544547. 